\title{
How to Relate Complex DNA Repair Genotypes to Pathway Function and, Ultimately, Health Risk
}

I.M. Jones

U.S. Department of Energy

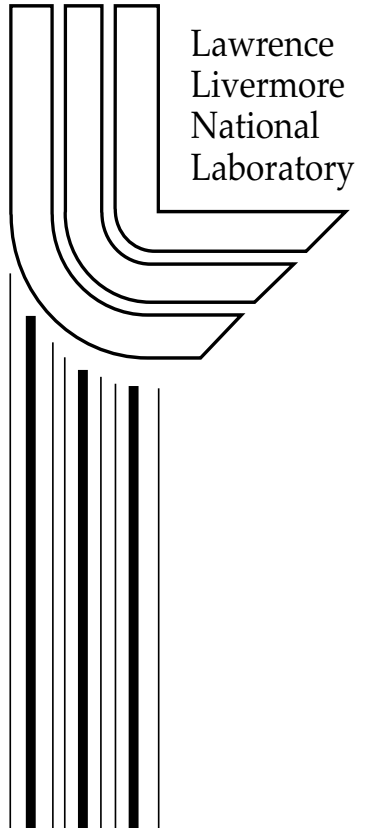

January 9, 2002

Approved for public release; further dissemination unlimited 


\section{DISCLAIMER}

This document was prepared as an account of work sponsored by an agency of the United States Government. Neither the United States Government nor the University of California nor any of their employees, makes any warranty, express or implied, or assumes any legal liability or responsibility for the accuracy, completeness, or usefulness of any information, apparatus, product, or process disclosed, or represents that its use would not infringe privately owned rights. Reference herein to any specific commercial product, process, or service by trade name, trademark, manufacturer, or otherwise, does not necessarily constitute or imply its endorsement, recommendation, or favoring by the United States Government or the University of California. The views and opinions of authors expressed herein do not necessarily state or reflect those of the United States Government or the University of California, and shall not be used for advertising or product endorsement purposes.

This work was performed under the auspices of the U. S. Department of Energy by the University of California, Lawrence Livermore National Laboratory under Contract No. W-7405-Eng-48.

This report has been reproduced directly from the best available copy.

Available electronically at http://www.doc.gov/bridge

Available for a processing fee to U.S. Department of Energy

And its contractors in paper from

U.S. Department of Energy

Office of Scientific and Technical Information

P.O. Box 62

Oak Ridge, TN 37831-0062

Telephone: (865) 576-8401

Facsimile: (865) 576-5728

E-mail: reports@adonis.osti.gov

Available for the sale to the public from

U.S. Department of Commerce

National Technical Information Service

5285 Port Royal Road

Springfield, VA 22161

Telephone: (800) 553-6847

Facsimile: (703) 605-6900

E-mail: orders@ntis.fedworld.gov

Online ordering: http://www.ntis.gov/ordering.htm

OR

Lawrence Livermore National Laboratory

Technical Information Department's Digital Library

http://www.llnl.gov/tid/Library.html 
UCRL-ID-146815

"How to Relate Complex DNA Repair Genotypes to Pathway Function and, Ultimately, Health Risk"

Final Report for LDRD Project 01-ERD-114

Irene M. Jones

Biology and Biotechnology Research Program

Livermore National Laboratory

\section{Background}

Exposure to ionizing radiation increases the incidence of cancer. However, predicting which individuals are at most risk from radiation exposure is a distant goal. Predictive ability is needed to guide policies that regulate radiation exposure and ensure that medical treatments have maximum benefit and minimum risk. Differences between people in susceptibility to radiation are largely based on their genotype, the genes inherited from their parents. Among the important genes are those that produce proteins that repair DNA damaged by radiation. Base Excision Repair (BER) proteins repair single strand breaks and oxidized bases in DNA. Double Strand Break Repair proteins repair broken chromosomes. Using technologies and information from the Human Genome Project, we have previously determined that the DNA sequence of DNA repair genes varies within the human population. An average of 3-4 different variants were found that affect the protein for each of 37 genes studied. The average frequency of these variants is $5 \%$. Given the many genes in each DNA repair pathway and their many variants, technical ability to determine an individual's repair genotype greatly exceeds ability to interpret the information.

A long-term goal is to relate DNA repair genotypes to health risk from radiation. This study focused on the BER pathway. The BER genes are known, variants of the genes have been identified at LLNL, and LLNL had recently developed an assay for BER function using white blood cells. The goal of this initial effort was to begin developing data that could be used to test the hypothesis that many different genotypes have similar DNA repair capacity phenotypes (function). Relationships between genotype and phenotype could then be used to group genotypes with similar function and ultimately test the association of groups of genotypes with health risk from radiation. Genotypes with reduced repair function are expected to increase risk of radiation-induced health effects.

\section{Purpose}

The goal of this pilot project was to obtain preliminary data on genetic variation in DNA repair function in human cells that might encourage our efforts to establish a research program to relate DNA repair function to complex DNA repair genotype and ultimately to cancer risk of radiation exposure.

\section{Activities}

The project was devoted to three aims: 1) adapting a methodology for studying DNA damage in human blood cells to studies of human cell lines; 2) using this assay to analyze the amount of DNA damage in cell lines before and at multiple times after they had been exposed to ionizing radiation ; and 3) beginning to relate these damage levels and the repair of radiation-induced damage to the particular variants of DNA repair genes each cell line has. 
Working with human lymphoblastoid cell lines. These cells have the potential to grow and divide forever. Between experiments cell lines are normally stored in suspended animation, in liquid nitrogen. It was necessary to determine several conditions for studying them. First, could cells be studied immediately after thawing or must they grow some to recover from freezing. Then it had to be determined whether the cells should be allowed to grow continuously, or to study them under conditions when no cells were dividing.

DNA damage measurements. For 48 different cell lines derived from healthy, unrelated Americans, DNA damage levels were measured using the single cell gel electrophoresis (Comet) assay conditions previously established in exponentially growing cells with no radiation and in cells exposed to $5 \mathrm{~Gy}$ of ionizing radiation at 3 time points, immediately after the cells were irradiated and after the cells were allowed 15 and 30 minutes to repair induced damage. For each cell line and experimental condition, the amount of damage present was measured in 100 cells prepared for analysis and stained with ethidium bromide using an image analysis system including a CCD camera, fluorescent microscope, and Komet4.0@: Image Analysis and Data Capture Software.

Relating DNA damage levels, repair and DNA repair genotype. Data on the genotypes for all the cell lines studied was extracted from records on the sequencing of 13 BER pathway genes. As little time remained for this activity, only simple relationships between genotype and these endpoints were assessed.

\section{Technical Outcome and Accomplishments}

We developed a simple protocol for working with human lymphoblastoid cell lines. We determined that it is necessary to allow cells to grow for almost one week before analysis. When cells are first thawed, there is considerable DNA damage in all cells, some cells are dead, and there is much variation from one experiment to another. By growing cells until over $90 \%$ of the cells are viable, more consistent results were obtained. It was determined also that, though having some cells dividing created some "noise" in the analysis, there was quick and easy method to obtain a healthy cell population with no dividing cells. There is considerable variation between cell lines in the time needed for cells to recover from being frozen.

DNA damage measurements in untreated cell lines and at several times after irradiation was our most time consuming task. The results, reflected in the figures below, demonstrate that there are differences in the amount of damage present in unirradiated cell lines (Figure 1). The "background" levels of damage ought to reflect the ability of cells to remove oxidative DNA damage that occurs normally during cell growth. If variation is this level is found to relate to cancer risk, it would be quite interesting and point to many other studies, such as whether diet might be used to reduce the amount of damage formed and therefore cancer risk.

There may be differences in the rate of repair of damage in different cell lines (Figure 2). We learned that most of the radiation-induced damage was removed quickly under the conditions used $\left(37^{\circ} \mathrm{C}\right)$. As a result we did not have the ability to discriminate differences in rates of repair between the cell lines. However, the observation that the amount of damage remaining 15 minutes after treatment with 5 Gy was directly related to the amount of damage present prior to radiation (Figure 3) could indicate that factors that lead to a low level of damage in untreated cells also may determine the amount of radiation-induced damage repaired. An assay that discriminates rates of repair of radiation-indiced damage is needed to really test this hypothesis. 
Relating DNA damage levels, repair and DNA repair genotype has led to very exciting preliminary findings. We did a number of analyses of DNA damage levels and a simple metric, of BER genotype, the number of variant alleles each cell line had. This metric captured all the known genetic differences in the genes in this pathway which is responsible for removing the type of damage assayed, single strand breaks and oxidized bases. The most striking relationship found was a direct relationship between the amount of background damage and the number of variant BER alleles in each cell line (Figure 4). This result is consistent with the amount of damage in the cells being determined by the ability of these genes. This is a very important finding. It provides support for our expectation that there would be a relationship between the genes and ability to control the level of this damage. Future studies will be needed to determine which variants, individually and in combination, have the most effect. Such studies will be needed if molecular epdimiologists are to be able to use genotype data directly to study cancer risk.

\section{Future Directions}

The results obtained encourage us to develop a funding base for a program to relate variation in DNA repair genes, DNA repair function and cancer risk from radiation exposures. Although very preliminary, the results already are leading to new opportunities. Two proposals for future research have been prepared. One is expected to lead to a pilot study with external radiation epidemiologists of breast cancer risk.

\section{Acknowledgments}

The author thanks Cynthia Thomas, Harvey Mohrenweiser and David O. Nelson for their contributions to the success of this project. This work was performed under the auspices of the U. S. Department of Energy by the University of California, Lawrence Livermore National Laboratory under Contract No. W-7405-Eng-48. This research is funded by the Laboratory Directed Research and Development (LDRD) Program at Lawrence Livermore National Laboratory (LLNL). The LDRD Program is mandated by Congress to fund director-initiated, long-term research and development $(\mathrm{R} \& \mathrm{D})$ projects in support of the DOE and national laboratories mission areas. The Director's Office LDRD Program at LLNL funds creative and innovative $\mathrm{R} \& \mathrm{D}$ to ensure the scientific vitality of the Laboratory in mission-related scientific disciplines. 
Figures

Figure 1. The amount of DNA damage in untreated cell lines (background damage") varies. The Comet Distributed Moment is a measure of the amount of damage present is each cell studied from single strand breaks and oxidized bases. 100 cells were analyzed for each data point.

Figure 2. The amount of damage removed after 5 Gy radiation may vary between cell lines. DNA damage was measured at four times: before radiation, immediately after radiation, and after 15 and 30 minutes of repair time at $37^{\circ} \mathrm{C}$. Plotted here is the amount of damage present normalized to the amount present immediately after radiation exposure.



Figure 3. Damage remaining in cells 15 minutes after exposure to 5Gy is related to the level of background damage. Linear regression analysis detected a strong direct relationship between the two measures of repair phenotype $\left(\mathrm{p}<4 \mathrm{x} 10 \mathrm{e}-5, \mathrm{R}^{2}=0.29\right)$.

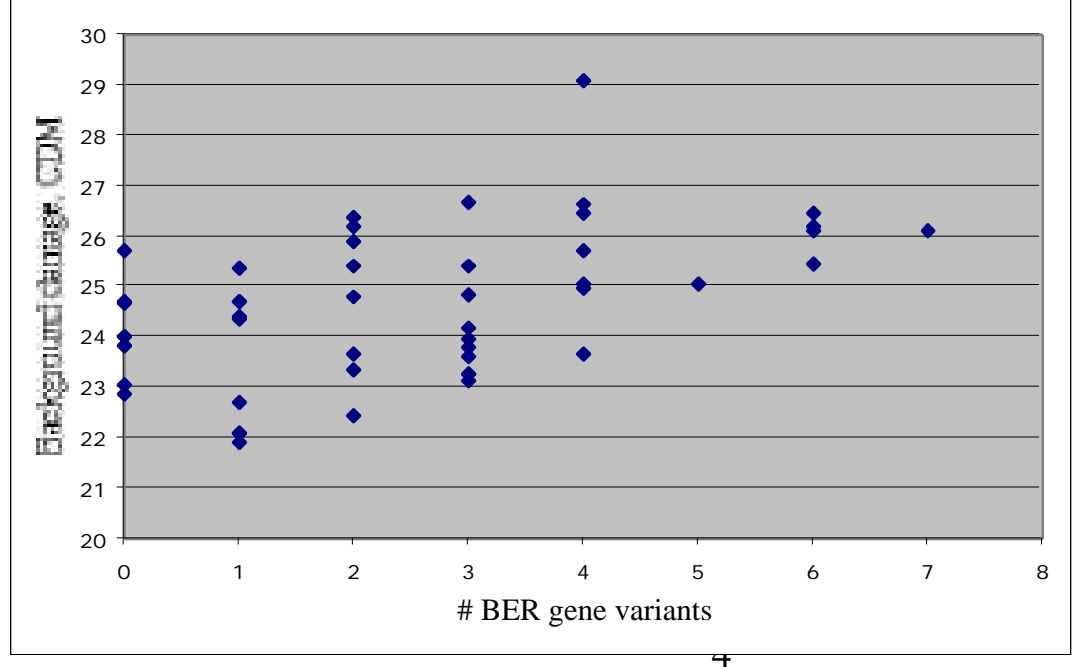


Figure 4. Background damage detected by the alkaline Comet assay is related to the BER genotype. The number of variant alleles for BER genes was counted for each of 48 cell lines. Linear regression analysis detected a strong direct relationship between genotype and phenotype $\left(\mathrm{p}=0.0005, \mathrm{R}^{2}=0.22\right)$.

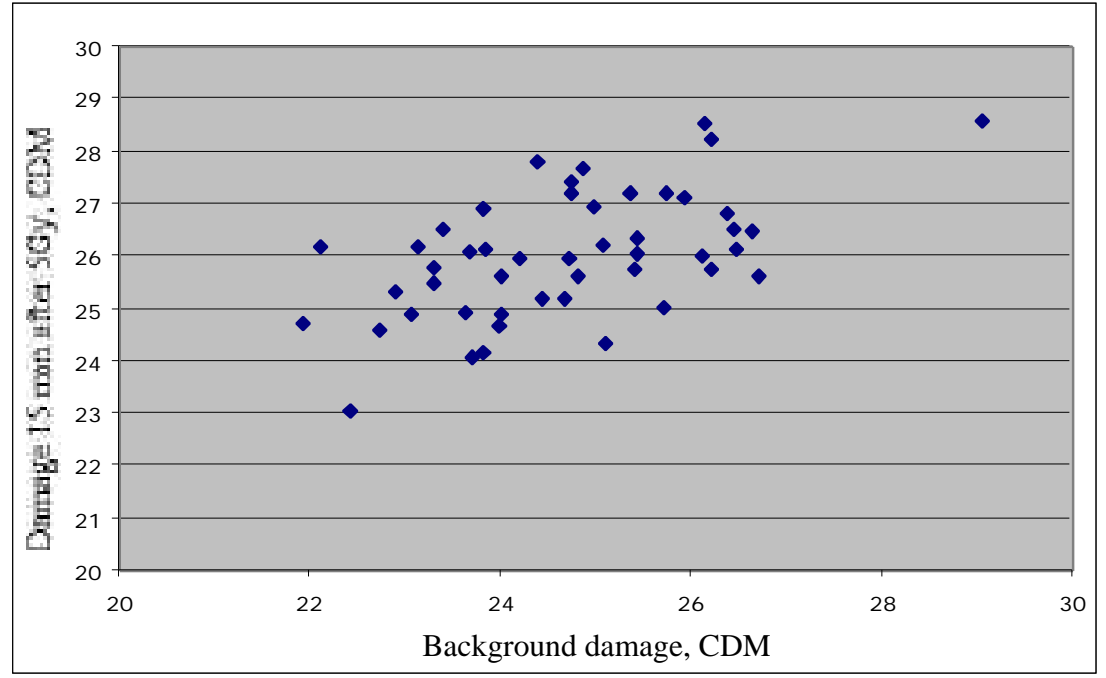

